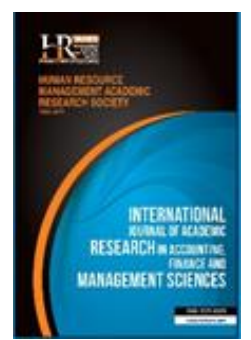

International Journal of Academic Research in Accounting, Finance and Management Sciences

Vol. 10, No.3, July 2020, pp. 38-51

E-ISSN: 2225-8329, P-ISSN: 2308-0337

(C) 2020 HRMARS

www.hrmars.com

To cite this article: Etale, L. M., Pouzigha, Y. A. (2020). Effect of Electronic Payment Systems on Payroll Fraud Prevention in Selected Ministries in Bayelsa State, International Journal of Academic Research in Accounting, Finance and Management Sciences 10 (3): 38-51.

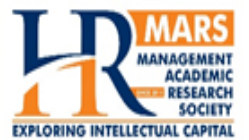

www.hrmars.com

ISSN: 2225-8329

\title{
Effect of Electronic Payment Systems on Payroll Fraud Prevention in Selected Ministries in Bayelsa State
}

\author{
Lyndon M. Etale ${ }^{1}$, Youpele A. Pouzigha ${ }^{2}$ \\ 1,2Department of Accounting, Faculty of Management Sciences, Niger Delta University, P. M. B. 071, Wilberforce Island, \\ Bayelsa State, Nigeria, ${ }^{2}$ E-mail: Iyndonetale@yahoo.com
}

\begin{abstract}
This study empirically examined the effect of electronic payment systems on payroll fraud prevention in selected Ministries in Bayelsa State. The specific objectives focused on effect of e-payment systems on payroll fraud prevention. To ascertain these objectives a survey research design was adopted and data for the study were collected using questionnaires that was structured on 5-point Likert summated rating scale. Multiple regression analysis was adopted to analyze the data. The findings of the analysis revealed that all the electronic payment system variables used (BIN, BVN and ETS) had positive effect on payroll fraud prevention, but the relationship was not significant at $5 \%$ level. Based on the findings, the study recommended that Government should take strict measures in ensuring full compliance in respect of BIN by every employee in the various Ministries in Bayelsa State. The study further recommends that every employee on Government payroll obtain a BVN in order to track financial transactions in the employee's salary account. It further enjoined Government to ensure that accountants in charge of salaries payment strictly adhere to electronic means of transferring employees' salaries and not manual payment.

Key words Electronic Payment Systems, Fraud, Payroll, Prevention

Received: 28 Jul $2020 \quad$ (C) The Authors 2020

Revised: 09 Aug 2020 Published by Human Resource Management Academic Research Society (www.hrmars.com)

Accepted: 12 Sep 2020 This article is published under the Creative Commons Attribution (CC BY 4.0) license. Anyone may Published Online: 21 Sep $2020 \quad$ reproduce, distribute, translate and create derivative works of this article (for both commercial and non-commercial purposes), subject to full attribution to the original publication and authors. The full terms of this license may be seen at: http://creativecommons.org/licences/by/4.0/legalcode
\end{abstract}

\section{Introduction}

Today's modern technology has changed businesses all over the world with the use of computer which makes payment system as an operational network governed by laws, rules and standards that links bank accounts and provides the functionality of monetary exchange using bank deposits (Summers, 2012). Traditional payment systems are negotiable instruments such as cheques and documentary credits such as letter of credits. With the advent of computers and electronic communications a large number of alternative electronic payment systems have emerged. These include debit cards, credit cards, electronic funds transfers, direct credits, direct debits, internet banking and e-commerce payment systems. Some payments include credit mechanisms, but that is essentially a different aspect of payment. Payment systems are used in lieu of tendering cash in domestic and international transactions and consist of a major service provided by banks and other financial institutions.

What makes it a "system" is that it employs cash substitutes with the use of electronic money and other ICT related equipment in its operations. The payment system is the infrastructure consisting of institutions, instruments, rules, procedures, standards and technical means established to effect transfer of monetary values between parties discharging mutual obligations. Its technical effectiveness determines the 
efficiency with which transactions in money are made in the economy and risk associated with its use (Bossone \& Cirasino, 2001). Electronic Payment Systems (EPS) apart from their convenience and safety also have a significant number of economic benefits which include mobilizing savings and ensuring most of the cash available in the country are with banks. This will make funds available to both corporate and individual borrowers. Furthermore, an electronic payment system has the ability to track individual spending; to facilitate the design of products by the banks. This information is also useful to the government when making decisions. EPS also have the ability to reduce cash handling and costs associated with printing manual payment instruments.

Payment systems may be physical or electronic and each has its own procedures and protocols. Standardization has allowed some of these systems and networks to grow at global scale, but there are still many countries and product - specific systems. Examples of payment systems that have become globally available are credit card and automated teller machine networks. Specific forms of payment systems are also used to settle financial transactions for products in the equity markets, bond markets, currency markets, futures markets, derivatives, option markets and to transfer fund between financial institutions both domestically using clearing and real time gross settlement (RTGS) systems and internationally using the SWIFT network.

According to Zandi (2013) real global GDP grew an extra $0.2 \%$ a year on average beyond what it would have been without card usage. Simply put card usage increases a country's GDP by $0.2 \%$ annually. Moving from a society where $90 \%$ of cash is held outside of the banks to a cashless society is a big change. It is therefore an enormous challenge for the government, financial institutions, individuals and other stakeholders responsible for making this system achieve its economic benefits. There are likely to be operational, financial, economic and marketing changes that need to be managed properly to ensure success with the electronic payment systems environment (Kumaga, 2010).

Nigeria payment system has been predominantly cash-based for both positive and negative reasons: positive because of its instant convertibility to other forms of value without intermediation by any financial institution; and negative because of its anonymity, lack of audit trail and ease of theft. The electronic payment system was therefore introduced because government was inundated with allegations of corruption in the financial system; worse in the public sector. The Federal Government of Nigeria through its treasury circular reference number TRY/A8 \& B8/2008 of October 22, 2008 directed that payments from all funds from it be made electronically as from January 1,2009 . The policy has been condemned by all and sundry for lack of planning, inefficiencies and delay in the payment for goods and services (Asaolu et al., 2011; Ogedebe \& Babatunde, 2012).

However, Omotubora \& Basu (2018) argued that electronic payment systems comes with their own set of problems, such as heavy cost of installation, cost of training, system failure, time consuming, breaches of security, health dangers and the danger of hackers stealing data. None of these studies attempted to evaluate the effect of electronic payment systems on payroll fraud prevention. Therefore, the purpose of this study is to ascertain the effect of electronic payment systems on payroll fraud prevention in selected Ministries in Bayelsa State.

\subsection{Statement of the Problem}

For a long time, payroll fraud has been difficult to deal with at the federal, state and local government levels. The problem of payroll fraud is now a national crisis and a huge drain on the nation's economy. The problem is so big, harmful and entrenched in the Nigeria bureaucracy that the nation is losing billions of Naira at all tiers of government (Oseloka, 2016). Government of Nigeria does not have the exact number of civil servants and her budget is always an estimate. This has created some loopholes, whereby some ministries budget more than they requires, and use the excess for some other things other than payment of salary and allowances.

Recent records showed that the Bayelsa State Government of Nigeria spends forty percent of its revenue on personnel costs every year at the detriment of other sectors of the economy. The problem of payroll fraud is far more rampant in the public service bureaucracy and less so in the organized private sector. This situation aroused government curiosity to ascertain the actual workforce through various exercise such as biometrics screening and personal verification (Oseloka, 2016). For instance, the recent 
staff verification exercise by the Bayelsa State Government has so far revealed that there are schools with staff in secondary and primary levels that are reported to be in the state payroll, whereas these schools are not found in the records of the state ministry of education all due to payroll fraud. Nevertheless, transparency and accountability still remain essential in solving payroll fraud challenges and caging the problem. Therefore, effort needs to be made to eliminate payroll fraud in the public sector. Hence, this study contributes to such efforts as it seeks to examine the effect of electronic payment systems on payroll fraud prevention in Nigeria, with emphasis in Bayelsa State.

\subsection{Objective of the study}

The main objective of this study is to ascertain the effect of electronic payment systems on payroll fraud prevention in selected Ministries in Bayelsa State. Therefore, this study is specifically to achieve the following objectives:

a. To determine the effect of biometric identification number on payroll fraud prevention

b. To determine the effect of bank verification number on payroll fraud prevention

c. To determine the effect of electronic transfer system on payroll fraud prevention

\subsection{Research Questions}

a. To what extent does biometrics identification number contribute to payroll fraud prevention?

b. To what extent does bank verification number contribute to payroll fraud prevention?

c. To what extent does electronic transfer system contribute to payroll fraud prevention?

\subsection{Research hHypotheses}

In examining the effect of electronic payment systems on payroll fraud prevention the following null hypotheses were formulated and tested:

1. Biometric identification number has no significant effect on payroll fraud prevention;

2. Bank verification number has no significant effect on payroll fraud prevention; and

3. Electronic transfer system has no significant effect on payroll fraud prevention.

\subsection{Significance of the study}

The findings of this study will assist the Government of Bayelsa State to overcome the problems of fraudulent diversion of public funds, looting of public funds, fake certificate and over and under aged workers in ministries, double timing in the payrolls of ministries, the ghost workers syndrome, financial leakages in the account of ministries, to curb payroll fraud and fraudulent activities in our society, and consequently increase the state's revenue needed to improve the living standard of the people.

This study is arranged into five parts. These includes the general introduction in part one above; review of related literature in part two; the methods adopted in carrying out the study is in part three; the data gathered for the study, results of analysis and discussions are covered in part four; while the summary, conclusion and recommendations have been taken up in part five.

\section{Literature review}

\subsection{Conceptual clarification}

Electronic Payment: The European Central Bank (ECB) defined e-payments as transactions made over the internet using distant payment cards, online banking instruments or e-payment providers with which the consumer has established relationships (ECB, 2010).

Fraud: It refers to an act or a course of deception deliberately practiced to gain unlawful or unfair advantage (payroll dictionary).

Payroll Fraud: It is the illegal manipulation of payroll systems to gain undue access to funds.

Electronic Payment Systems

The term electronic payment system can be referred narrowly to e-commerce - a payment for buying and selling goods and services offered through the internet, or broadly to any type of electronic funds transfer (Cirasino \& Garcia, 2008). Guttman (2003) defined electronic-payment system as credit card 
details, or some other electronic means, as opposed to payment by cheques and cash. It is also defined as a payer's transfer of monetary claim on a party acceptable to the beneficiary (Worku, 2010). Vassiliou (2004) defined electronic payment system as a form of financial exchange which takes place between the buyer and seller facilitated by means of electronic communication. Humphrey, Kim \& Vale (2001) defined epayment as cash and associated transactions implemented using electronic means. Typically, this involves the use of computer networks such as the internet and digitally stored value system. This system allows bills to be paid directly from bank, and without the use of writing and mailing cheques. Ayodele (2015) defined e-payment as electronic transfer of cash via online transactions for business-to-business (B2B), business-to-consumer (B2C), person-to-person (P2P), and most recently administration-to-consumer (A2C) purposes. $\mathrm{A} 2 \mathrm{C}$ payment mode addresses the payment of taxes the government.

In the Nigeria context, e-payment is the means of effecting payments from one end to another and through the medium of the computer without manual intervention beyond inputting the payment data. It is the ability to pay the suppliers, vendors and staff salaries electronically at the touch of a computer button (Agba, 2010). Electronic payment can also be defined as convenient, safe and secure methods for payment of bills and other transactions by electronic means such as card, telephone, the internet, EFT, etc. Electronic payment gives consumers an alternative to paying bills and debt obligations by cash, cheque, money order, etc. Its main purpose is to reduce cash and cheque transactions. The Government of Bayelsa State takes the use and application of computerized accounting e-payment system with a high regard because of its usefulness in managing very high personnel cost as well as reduction of fraud in our state payroll.

\subsection{Types of electronic-payment}

In the Nigeria context, there are two types of electronic-payment namely:

i. End to End processing: Here, all the processes from approvals to the receipt of value by the beneficiary are done electronically; and

ii. Manual e-payment or use of Mandate: It is the mixture of manual and electronic process where the available infrastructures cannot support the end-to-end processing.

However, there are many forms of e-payments; these include cards, internet mobile payments, electronic point of sale (POS) service kiosks, electronic payment networks (Osibote, 2010; and Asaolu et al., 2011).

\subsection{Economic Benefits of Electronic Payment System in Nigeria}

The use of internet has brought about an increase in e-payments with a wide variety of new secure network payment schemes such that consumers can buy goods online and make payment with credit or debit cards (Kumaga 2010). Electronic payments as argued by Taddesse \& Kidan (2005) have a significant number of economic benefits apart from their convenience and safety. These benefits when maximized can go a long way in contributing immensely to economic development of a nation. According to them, efficient, safe and convenient electronic payments come with significant range of macroeconomic benefits. The impact of introducing electronic payments is akin to using the gears on a bicycle; add an efficient electronic payments system to an economy, and you kick it into a higher gear; add better controlled consumer and business credit, and you notch up economic velocity even further (Taddesse \& Kidan, 2005).

Electronic payment systems can help displace shadow economies, bring hidden transactions into the banking system and increase transparency, confidence and participation in the financial system. Worku (2010) emphasized the fact that electronic payment lowers costs for businesses. The more payments that is processed electronically, the less money is spent on paper and postage. Offering electronic payment can also help businesses improve customer retention.

\subsection{Challenges of Electronic Payment System}

Electronic payment system with its numerous benefits has its own challenges. Sumanjeet (2009) listed the following as problems militating against e-payment even in the developed world:

- Integrity: to ensure that transmitted financial information is unchanged in transit.

- Non-reputation: to ensure that all parties have non-deniable proof of receipt. 
- Confidentiality: to ensure that transactions are protected from possible eavesdroppers.

- Reliability: to ensure that there is reduced possibility of failure.

-Authorization: to ensure that individuals are recognized and granted the desired rights and privileges.

\subsection{Electronic Payroll System}

The following are the important characteristics of a good payroll system:

i. Ability to calculate taxes: This include: Federal income, Social security

Medicare, State income, and City income;

ii. Indicates Government's employment rate;

iii. State disability insurance;

iv. Support for different types of deductions; and

v. Ability to print pay slips and create detailed reports.

\subsection{Biometrics Identification Number}

The following are benefits associated with the use of biometric technology:

i. Registration of fake workers is eradicated in the payroll system.

ii. Fake time sheets or buddy punching is minimized to the barest minimum.

iii. Salaries are not erroneously paid to the wrong employees.

iv. With the eradication of ghost workers, government realizes high ROI.

Nevertheless, there have been some challenges. One of the major problems was the illegal manipulation in the Bayelsa State payroll system by users who dubiously and falsely entered fake identities to rob the state government of benefits they had no entitlement to. The Establishment Committee headed by Mr. Francis Doukpola, in its report to the Government of Bayelsa State on the actual staff strength and wage bill of the state between 2007 and 2015, observed some discrepancies between the nominal roll and payroll of most of the ministries; and advised the Government to put in place a monitoring mechanism to ensure that both of them tally at any given point in time to check payroll fraud (Utebor, 2016). The observed discrepancies between nominal roll and payroll figures are due to payroll fraud. Sometimes those who commit payroll fraud when caught would claim that ghost (or non-existent) workers were staff on study leave.

\subsection{Bank Verification Number (BVN)}

The project aims to achieve the following advantages:

i. Tackle identity theft problem to prevent account fraud.

ii. Easy identification of blacklisted staff.

iii. To curb payroll fraud

iv. To protect against ghost workers in the payroll

v. Eradicate fraudulent activities in the payroll.

vi. Increased accessibility to banking operations

\subsection{Payroll Fraud}

A payroll is a list of employee's salaries and wages, bonuses, number of withholding allowances and voluntary deductions (Nnanta \& Eme, 2013). For the purpose of this study fraud refers to an act or a course of deception deliberately practiced to gain unlawful or unfair advantage (Payroll dictionary). Adongoi and Victor (2016) defined payroll fraud as a theft of cash from an organization through the payroll process; the culprits could be the employee or a co-employee who is using the employee to commit fraud while taking the fraud proceeds for personal use. Nevertheless, payroll fraud can be defined as an unauthorized removal of employee's emoluments. The following are the notable example of payroll fraud: ghost employees; false employee's claims; and time theft: 
Ghost Workers

* Creating a ghost worker and inserting ghost names into the payroll system

* Falsifying time sheets

* Collecting and converting payments

\section{False Employees Claims}

This kind of fraud is associated with dishonest workers within the organization who have planned to attack the payroll and expense reimbursement system of a business (ACFE Global Fraud Report, 2016). They fall into two main areas:

- False expense claims fraud and

- False pay claims fraud

Time Theft

This is described as getting paid for the time not worked for at all but recorded as having worked. For instance the US Census Hiring and Employment Check (CHEC) Office had regularly been recording and paying employees for time not actually worked since 2010 (US Census Bureau Investigative Report, 2015). Humaira (2015) explains that time theft is so serious that it can affect organization input and productivity in a very negative way and has a way of diminishing profitability in the public service. Examples of time thefts include time clock theft, proxy attendance, buddy punching, over extended breaks, excessive personal time, among others. The five most popular forms of time theft in the public service include:

- Excessive Personal Time:

- Overextended Breaks:

- Internet Time Theft

- Time Card Fraud:

- Ghost Employees:

\subsection{Ghost Employees}

Ghost employee is another kind of time theft which can occur in several different ways. The first example is a situation whereby a real employee nonchalantly clocks into the office (for sake of just signing in for the day's work) and then in the next minutes he disappears to do some other personal things at the expense of the organization. The whole game is complete when the fraudulent employee comes back at the end of the day to sign out - a false indication of having completed the day's work.

\section{Nigeria}

\subsection{Success Stories Using Electronic Payment Systems to Eliminate Payroll Fraud in the MDAs in}

The implementation of bank verification number (BVN) and biometric identification number (BIN) are steps taken by governments to check payroll fraud. Biometric identification is accurate, secure, and end user solutions are specifically designed to be user friendly to help bring convenience to the public service. The biometric identification number (BIN) and bank verification number (BVN) has helped to eliminate ghost workers from the payroll of several tiers of government of Nigeria. The Government of Bayelsa State explained that it constituted various committees to use the BIN and BVN details of workers to check for ghost workers and identify duplicate and other irregular entries on the payroll.

\subsection{Theoretical Framework}

\subsubsection{Fraud Triangle Theory}

The fraud triangle theory identifies the key elements that lead perpetrators to commit fraud in any organization. According to Dorminey et al. (2010), the origin of the theory dates back to the works of Sutherland, who coined the term "white collar crime"; and that Cressey (1953), one of Sutherland's former students, focused his research on the circumstances that lead individuals to engage in fraudulent and unethical activity; the research later became known as the fraud triangle theory. The fraud triangle theory consists of three elements that are necessary for theft or fraud to occur: (a) perceived pressure, (b) 
opportunity and (c) rationalization. Albrecht, Hill, and Albrecht (2006) compared this theory to a fire using the simple explanation that three elements are necessary for a fire to occur: (a) oxygen, (b) fuel and (c) heat. Like fire, fraud is unlikely to exist in the absence of the three elements mentioned in the fraud triangle theory, and the severity of fraud depends on the strength of each element. In other words, for an individual to make any unethical decision, perceived pressure, an opportunity, and a way to rationalize the behavior must exist.

\subsubsection{Empirical Review}

Okoro (2014) examined the impact of selected e-payment instruments on the inter-mediation efficiency of the Nigerian economy using time series data from 2006 to 2011 and employing multiple regression technique using intermediation efficiency indicators. The study discovered that there was a significant relationship between ATM, POS, Internet service values and the intermediation efficiency of the Nigerian economy. Other studies by Acha et al. (2017), Joseph and Richard (2015) and Yaqub et al. (2013) examined the benefits and challenges of the e-payment system. Further studies by Kujur \& Shah (2015) considered the impediments some developing countries may face while adopting the electronic payment system. Mago \& Chitokwindo (2014) opined that the e-payment strategy has significantly affected the growth of online businesses, thereby creating diversification in the e-commerce ICT industries.

Kombo (2013) examined the effect of electronic accounting system (EAS) on improving auditing process. Descriptive statistics and cross tabulation were used to analyses data using statistical package of social science (SPSS). This study revealed that the contributions of EAS to the effectiveness and efficiency of the auditing process is moderate. In a similar research Scovia \& Callist (2015) investigated the impact of automated accounting system on financial reporting. The study revealed that computerized accounting system has proved to be effective in providing information regarding the financial position of an entity in a timely and efficient manner.

Emmanuel (2015) investigated computerized accounting system as an effective means of keeping accounting records. The study revealed that the computerized accounting system is an effective means of keeping accounting records. This is because computerized accounting system provides a means for them to record; very high volume of transactions with great speed, and computerized accounting financial reports presents a wide range of detailed financial information. It also provides management with up-to-date current account balance information since balances are posted online and real-time as the transaction occur.

Another research by Mejabi (2006) examined the impact of automated accounting system on payroll preparation in some selected large organizations. The hypotheses were tested using correlation coefficient, analysis of variance (ANOVA). The result revealed that application of modern computer packages may not necessarily bring permanent solution to accounting and payroll processing problems in organizations. Finally, Nnanta \& Eme (2013) worked on the pros and cons of e-payment system in wages/salaries administration, as well as factors that affect the applicability of the system. The study found out that the expected benefits derivable from an e-payment system exceed the cost/challenges associated with it.

\section{Methodology of research}

\subsection{Research Design}

The survey research design was employed due to the nature of the study, which relates to collecting data from a vast population. The design was used because it would allow the researcher to obtain data relevant for the purpose of the study.

\subsection{Variable of the study}

The independent variables of this study are the identified components of electronic payment systems (EPS) such as biometric identification number (BIN), bank verification number (BVN) and electronic transfer system (ETS) which in apriority expectation would lead to payroll fraud prevention (PFP), the dependent variable. 


\subsection{Sources of Data}

For the purpose of this study, primary data were collected through the administration of questionnaire to staff in the Accounts and Payroll Units of the four (4) ministries (Finance, Education, Works and Transport) of Bayelsa State selected for the study.

\subsection{Model Specification}

For the purpose of this study, both the independent and dependent variables were identified. We adopted and modified a multiple regression model [which had severally been used by previous researchers such as Etale \& Uzakah (2020), Antwi et al. (2013), Ismaila \& Imoughele (2015), Nwoye et al. (2015), and Owolabi \& Adegbite (2014) to mention a few] to capture the interrelationship between e-payment system variables and payroll fraud prevention in the selected ministries in Bayelsa State. The study analysis using SPSS was therefore based on the following model: PFP $=\int(B I N, B V N, E T S)$. To make the model easy for empirical verification, we transform it into a multiple linear regression equation as shown below:

$$
P F P=\alpha+B_{1} B I N+B_{2} B V N+B_{3} E T S+e
$$

Where: $P F P=$ Payroll fraud prevention (dependent variable)

$B I N=$ Biometric identification number

$B V N=$ Bank verification number

$E T S=$ Electronic transfer system

$\alpha=$ Represents the intercept of the slop

$B_{1}, B_{2}$, and $B_{3}=$ Regression coefficients of $B I N, B V N$ and $E T S$ to determined

$e=$ error term of the equation

\subsection{Method of data analysis}

The multiple regression analysis was used for data analysis. Multiple regression technique as a statistical tool for analyzing data has the following merits: It allows researchers to utilize more of the information available to estimate the dependent variable. It also possesses the unique qualities of unbiasness, consistency and efficiency. The statistics tested for include the coefficients of the independent variables, coefficient of determination of the regression equation, T-test, F-test and Durbin Watson (DW) statistics. The statistical Package for Social Sciences (SPSS) windows 20 was the computer software used in running the regression analysis. The coefficient of determination $\left(R^{2}\right)$ test: it measures thee explanatory power of the independent variables on the dependent variable. The T-test: it measures the individual significance of the estimated independent variables. The F-test: it measures the overall statistical significance of the model. It is used to generalize the hypotheses. Durbin Watson (DW) statistics: it is a test for auto-correlation among the independent variables.

\section{Data presentation, results, and discussions}

\subsection{Presentation of Data}

\subsubsection{Response Rate of Questionnaire Administration}

For the study, a total of 365 copies of the questionnaire were distributed to staff drawn from the accounting departments and payroll units of the identified four (4) Ministries (Finance, Education, Works and Transport) selected out of the Twenty-One (21) Ministries in Bayelsa State for the study. Out of the 365 copies of the questionnaire administered, a total of 325 were retrieved and used for the study, representing $89 \%$ response rate. 40 copies of questionnaires representing $11 \%$ were not returned as shown in Table 1.

Table 1. Computation of Response Rate (Questionnaire Distribution and Collection)

\begin{tabular}{|c|l|c|c|}
\hline S/N & \multicolumn{1}{|c|}{ Description } & Quantity & Percentage \\
\hline 1. & Number of Questionnaire Distributed & 365 & $100 \%$ \\
\hline 2. & Number of Questionnaire Returned & 325 & $89 \%$ \\
\hline 3. & Number of Questionnaire Not-Returned & 40 & $11 \%$ \\
\hline
\end{tabular}

Source: Researcher Field Survey, 2020 


\subsubsection{Questionnaire Analysis on Personal Data (Ministries)}

The questionnaire response rate from staff of the sampled Ministries involved in the study is presented in Table 2.

Table 2. Response Rate from Various Ministries

\begin{tabular}{|c|c|c|c|}
\hline S/N & Name of Ministry & Retrieved Copies of Questionnaire & Percentage $\%$ \\
\hline 1. & Finance & 95 & $29.23 \%$ \\
\hline 2. & Education & 76 & $23.38 \%$ \\
\hline 3. & Works & 84 & $25.85 \%$ \\
\hline 4. & Transport & 70 & $21.54 \%$ \\
\hline \multicolumn{2}{|l|}{ TOTAL } & 325 & $100 \%$ \\
\hline
\end{tabular}

Source: Researcher Field Survey, 2020

\subsection{Analysis and classification of data}

The responses received were now analyzed and classified for the adopted study variables: Payroll fraud prevention (PFP), the dependent variable; and for the independent variables and components of Electronic payment systems such as Biometric identification number (BIN), Bank verification number (BVN) and Electronic transfer system (ETS) in Table 3, Table 4, Table 5 and Table 6 (these Tables are shown in appendices 1-4). The data in Tables 3-6 were summarized and presented in Table 7 to make it easy for OLS multiple regression analysis using windows SPSS computer software.

Table 7. Summarized data of the study variables

\begin{tabular}{|c|c|c|c|c|c|}
\hline No of observation & PFP & BIS & BVN & ETS & TOTAL \\
\hline 1 & 3.68 & 3.71 & 3.58 & 3.72 & 14.69 \\
\hline 2 & 3.72 & 3.63 & 3.64 & 3.72 & 14.71 \\
\hline 3 & 3.59 & 3.69 & 3.59 & 3.63 & 14.50 \\
\hline 4 & 3.70 & 3.87 & 3.81 & 3.73 & 15.11 \\
\hline 5 & 3.72 & 3.70 & 3.74 & 3.76 & 14.92 \\
\hline TOTAL & 18.41 & 18.60 & 18.36 & 18.56 & 73.93 \\
\hline
\end{tabular}

Source: Compiled from Tables $3-6$ of Field Survey 2020

\subsection{Results of data analysis}

The regression results for the effect of Electronic payment systems variables on Payroll fraud prevention of selected Ministries in Bayelsa State of Nigeria are shown in Table 8. Following these results, the regression can be stated as shown below:

$$
P F P=0.197+0.143 B I N+0.099 B V N+0.984 E T S+0.0299
$$

\subsection{Discussion of Findings}

Table 8 shows the summary of the regression results of the effect of Electronic payment systems on Payroll fraud prevention in selected Ministries in Bayelsa State of Nigeria, particularly, the Electronic payment systems variables and their significant effects on payroll fraud prevention. From the result, it is now obvious that the effect of Electronic payment systems variables positively affected the Payroll fraud prevention in the Ministries of Bayelsa State of Nigeria, as indicated by the calculated beta and probability values of the independent variables (beta values $0.143,0.099$ and 0.984 ; P-values $0.683,0.788$ and 0.255 for BIN, BVN and ETS respectively). This means that all the independent variables are positively related to the dependent variables of the study, but the effect is not significant at $5 \%$ level (since the P-values of BIN, BVN and ETS; $0.683,0.788$ and 0.255 are each greater than 0.05 ). 
Table 8. Regression Results

\begin{tabular}{|l|c|c|c|c|c|}
\hline \multirow{2}{*}{ Model } & \multicolumn{4}{|c|}{ Coefficients } \\
\cline { 2 - 6 } & Unstandardized Coefficients & \multicolumn{2}{c|}{ Standardized Coefficients } \\
\cline { 2 - 6 } & Beta & Std. Error & & T & Sig \\
\hline Constant & 0.197 & 1.406 & & 0.140 & 0.911 \\
\hline BIN & 0.143 & 0.263 & -0.237 & 0.545 & 0.683 \\
\hline BVN & 0.099 & 0.286 & 0.183 & 0.346 & 0.788 \\
\hline ETS & 0.984 & 0.417 & 0.887 & 2.361 & 0.255 \\
\hline
\end{tabular}

a. Dependent Variable PFP

b. Predictors; (Constant), ETS, BIN, BVN

$R=0.961, R^{2}=0.923, R^{2}$ adjusted $=0.693 \mathrm{~S}$. E. of Regression $=0.0299$

F-statistics $=4.004$ sig. F. change $=0.346$ Durbin Watson $(D W)=2.515$

Source: SPSS Windows 20 Output

However, the explanatory power of the model as informed by the R-square value of 0.923 means that the combined effect changes in the independent variables explained $92 \%$ of resultant changes in the dependent variable. The adjusted R-square value of 0.693 means that one can say with $69 \%$ confidence that the model adopted for this analysis is a proper and good fit. The relatively high adjusted R-square of 0.693 (or 69\%), shows that the regression model fits the data well. Only about $31 \%$ variation in Payroll fraud prevention can be explained by other unknown variables not captured in the present model. Therefore, the model used is robust enough for electronic payment systems to be used to control payroll fraud in conjunction with others.

The probability of F-statistics value of 0.348 (which is greater than the 0.05 level of significance) indicates that, overall, Electronic payments systems have positive but insignificant effect on Payroll fraud prevention. This is too worrisome since the components used could not take account of other human factor including employee collusion in perpetrating fraud.

Besides, the Durbin Watson (DW) value of 2.515 can be approximated to the 2.0 benchmark of noauto correlation among the independent variables. This implies that there is no auto correlation among the independent variables of the study. The test of significance shows that all the variables are insignificant when the calculated P-values in Table 8 are compared with the critical value of 0.05 (at $5 \%$ level of significance). But in specific terms, a unit of increase or decrease in BIN, BVN, and ETS would lead to an increase or decrease in Payroll fraud in Ministries in Bayelsa State with a margin of 0.143, 0.099 and 0.984 respectively.

\section{Summary, conclusions and recommendations}

\subsection{Summary}

The crux of this study was to examine of the effect of e-payment systems on payroll fraud prevention in Ministries in Bayelsa State of Nigeria. It was empirically verified that all the e-payment systems variables had positive effect on payroll fraud prevention in Ministries in Bayelsa of Nigeria, but the effect is not significant at $5 \%$ level:

a) Biometric identification number had positive effect on payroll fraud prevention with beta value of 0.143 ;

b) Bank verification number had positive effect on payroll fraud prevention with beta value of 0.099 ; and

c) Electronic transfer system had positive effect on payroll fraud prevention with beta value of 0.984 .

\subsection{Conclusions}

This study empirically examined the effect of electronic payment systems on payroll fraud prevention in selected Ministries in Bayelsa State. The specific objectives focused on effect of e-payment systems on payroll fraud prevention. To ascertain these objectives a survey research design was adopted and data for 
the study were collected using questionnaires that was structured on 5-point Likert summated rating scale. Multiple regression analysis was adopted to analyze the data. The findings of the analysis revealed that the electronic payment system variables (BIN, BVN and ETS) had positive effect on payroll fraud prevention. Also, it was observed that all the independent variables were positively related to the dependent variable of the study but the relationship was not significant at $5 \%$ level. The study concluded that electronic payments systems have positive effect on payroll fraud prevention.

\subsection{Recommendations}

From the findings of this study, the following recommendations are proffered;

1. The study suggest that Government, Head of Ministries, Department or Units should take adequate steps and ensure full compliance in respect of BIN by every employee in the various Ministries in Bayelsa State;

2. The study also suggested that Government of Bayelsa State should ensure that every employee receiving salary obtain a BVN in order to track financial transaction in the employee's salary account; and

3. Government should ensure that accountants in charge of salary payment adhere strictly to electronic means of transferring employees' salaries and stop henceforth the use of manual payments.

\section{References}

1. Acha, I. A., Kanu, C., \& Agu, G. A. (2017) Cashless policy in Nigeria: The mechanics, benefits and problems, Innovative Journal of Economics and Financial Studies, 1(1), 28-38

2. Adongoi, T., \& Victor, E. A. (2016) Corruption in the civil service: A study of payroll fraud in selected Ministries, Departments and Agencies (MDAs) in Bayelsa State, Nigeria, Research in Humanities and Social Sciences, 6(3), 53-69

3. Agba, D. (2010) Implications and challenges of E-payment system, March 12, www.itnewafrica.com Accessed 28/05/2020

4. Albrecht, W. S., Hill, N. C., \& Albrecht, C. C. (2006) The ethics development model applied to declining ethics in accounting, Australian Accounting Review, 16 (1), 30-40

5. Antwi, S., Mills, E. F. E. A., \& Zhao, X. (2013) Impact of macroeconomic factors on economic growth in Ghana: A co-integration analysis, International Journal of Academic Research in Accounting, Finance and Management Sciences, 3(1), 35-45

6. Asaolu, T. O., Ayoola, T. J., \& Akinkoye, E. Y. (2011) Electronic payment system in Nigeria: Implication, constraints and solutions, Journal of Management and Society, 1(2), 16-21

7. Association of Certified Fraud Examiners (2016) Report to the Nations on Occupational Fraud and Abuse, ACFE Global Fraud Study,1-92 www.acfe.com/rttn2016/docs Accessed 28/05/2020

8. Ayodele, T. D. (2015). Nigerian payment systems through electronic banking: A review, International Journal of Transformation in Business Management, 5(11), 27-35

9. Bossone, B., \& Cirasino, M. (2001) The oversight of payment systems: A framework for the development and governance of payment systems in emerging economies, Payment and Securities Clearance and Settlement Systems Research Series No. 1, CEMLA The World Bank, 1-66 www.semanticscholar.org Accessed 28/05/2020

10.Cirasino, M., \& Gracia, J. A. (2008) Measuring payment system development, Financial Infrastructure Series, Payment Systems Policy Research, The World Bank

11.Cressey, D. R. (1953) Other People's Money, Patterson Smith, New Jersey

12.Dorminey, J., Fleming, A., Kranacher, M., \& Riley, R. (2010) Beyond the fraud triangle, The CPA Journal, 80(7), 17-23

13.Emmanuel, O. W. (2015) Computerized accounting system an effective means of keeping accounting records in Ghanaian banks: A case study if the GaRural Bank, International Journal of Research in Business Studies and Management, 2(11), 111-141

14.Etale, L. M., \& Uzakah, T. (2020) Financial Accounting performance indicators and share price: A case study of Zenith Bank Nigeria PLC, Niger Delta Journal of Management Sciences, 1(1), 62-79

15.European Central Bank (2010) Payment statistics www.ecb.europa.eu Accessed 28/05/2020 
16.Guttman, R. (2003) Cybercash: The Coming Era of Electronic Money, Palgrave Macmillan, Basingstoke

17. Humaira, H. (2015) Internal Finance and growth: Comparison between firms in Indonesia and Bangladesh, International Journal of Economic and Financial Issues, 5(4), 1038-1042

18. Humphrey, D. B., Kim, M., \& Vale, B. (2001) Realizing the gains from electronic payments, cost, pricing choice, Journal of Money, Credit, and Banking, 33 (2), $216-234$

19.Ismaila, M., \& Imoughele, L. E. (2015) Macroeconomic determinants of economic growth in Nigeria: A co-integration approach, International Journal of Academic Research in Economics and Management Sciences, 4(1), 34-46

20.Joseph, O., \& Richard, I. (2015) Electronic payment system in Nigeria: Its economic benefits and challenges, Journal of Education and Practice, 6(16), 56-62

21.Kombo, B. (2013) The effects of computerized accounting system on auditing process: A case study of Mtwara District Council (MDC), MSc Accounting and Finance Degree Thesis, University of Mzumbe, 1-87 www.scholar.mzumbe.ac.tz>handle Accessed 28/05/2020

22.Kujur, T., \& Shah, M. A. (2015) Electronic banking: Impact, risk and security issues, International Journal of Engineering Management, 5(5), 207-212

23.Kumaga, D. (2010) The challenges of implementing electronic payment system: The case of Ghana's E-zwich payment system, MBA Thesis of the Institute of Technology, School of Management, 1-55 www.academia.edu Accessed 28/05/2020

24.Mago, S., \& Chitokwindo, S. (2014) The Impact of mobile banking on financial Inclusion in Zimbabwe: A case for Masvingo Province, Mediterranean Journal of Social Sciences, 5(9), 221-230

25.Mejabi, F. (2006) The impact of automated accounting systems on payroll preparation in some large organizations, MSc Dissertation of Covenant University, Nigeria, 1-80

26.Nnanta, N. E., \& Eme, O. I. (2013) An analysis of computerized accounting and payroll system on monthly emolument in Nigeria local government, International Journal of Accounting Research (IJAR), 1(3)

27.Nwoye, U. J., Obiorah, J., \& Ekesiobi, C. (2015) Effect of Nigeria macroeconomic environment on the performance of the national economy: Implications, International Journal of Academic Research in Business and Social Sciences, 5(7), 42-51

28. Ogedebe, P. M., \& Babatunde, P. J. (2012) E-payment: Prospects and challenges in Nigerian public sector, International Journal of Modern Engineering Research (IJMER), 2 (5), 3104-3106

29. Okoro, A. S. (2014) Impact of electronic banking instruments on the intermediation efficiency of the Nigerian economy, International Journal of Accounting Research, 1(6), 14-21

30.Omotubora, A., \& Basu, S. (2018) Regulation for e-payment systems: Analytical approaches beyond private ordering, Journal of African Law, 62(2), 281-313

31.Oseloka, H. O. (2016) Caging Nigeria's ghost workers, March 7 www.sunnewsonline.com

32.Osibote, I. I. (2010) E-payment system: Processes, procedures, challenges and prospects, A Paper Presented at a workshop in Abuja on March 15, www.finacial.tmcnet.com/mergeracquitions/news Accessed 28/05/2020

33. Owolabi, U. \& Adegbite, T. A. (2014) Impact of monetary policy on industrial growth in Nigeria, International Journal of Academic Research in Business and Social Sciences, 4(1), 18-31

34.Scovia, M., \& Callist, K. (2015) The impact of computerized accounting system on financial reporting in the Ministry of Local Government of Rwanda, Journal of Emerging Trends in Economics and Management Sciences, 6(4), 261-265

35.Sumanjeet, S. (2009) Emergence of payment systems in the age of electronic commerce: The state of art, Global Journal of International Business Research, 2(2), 17-36

36.Summers, B. J. (2012) Payment Systems - Design, Governance and Oversight, Central Banking Publications, London

37.Taddesse, W., \& Kidan, T. G. (2005) E-payment: Challenges and opportunities in Ethiopia, United Nations Commission for Africa, 1-58 www.ethioconstruction.net Accessed 28/05/2020

38.US Census Bureau Investigative Report (2015) Allegations of time and attendance fraud and other misconduct by employees in the Census Hiring and Employment Check (CHEC) Office, US Department of Commerce, Report No. 14-0790, 1-62 www.oig.doc.gov Accessed 28/5/2020 
39.Utebor, S. (2016) Dickson sacks civil servants on unapproved study leave, Punch, October 6, www.punchng.com>latest-news Retrieved on 28/5/2020

40.Vassiliou. (2004) Electronic payment system in Nigeria: Its economic benefits, IEEE Journal of Solid State Circuits, 39(7), 1180-1184

41.Worku, G. (2010) Electronic banking in Ethiopia - Practices, Opportunities and Challenges, Journal of Internet Banking and Commerce, 12(2), 24-36

42.Yaqub, J. O., Bello, H. T., Adenuga, I. A., \& Ogundeji, M. O. (2013) The cashless policy in Nigeria: Prospects and challenges, International Journal of Humanities and Social Sciences, 3(3), 200-212

43.Zandi, M. M. (2013) The impact of electronic payments on economic growth, Moody's Analytics (Economic and Consumer Credit Analytics), 1-16 www.usa.visa.com Accessed 28/05/2020

Appendix: 1 Analysis and Classification of Evaluation of Payroll fraud prevention

Table 3. Evaluation of Payroll Fraud Prevention

\begin{tabular}{|c|c|c|c|c|c|c|c|c|}
\hline S/N & ITEMS & $\begin{array}{l}\text { SA } \\
(5)\end{array}$ & $\begin{array}{c}A \\
(4)\end{array}$ & $\begin{array}{c}U \\
(3)\end{array}$ & $\begin{array}{c}D \\
(2)\end{array}$ & $\begin{array}{l}\text { SD } \\
(1)\end{array}$ & TOTAL & MEAN \\
\hline \multirow[t]{2}{*}{1} & \multirow{2}{*}{$\begin{array}{l}\text { Physical and electronic surveillance activities } \\
\text { ensure payroll fraud prevention }\end{array}$} & 99 & 134 & 0 & 77 & 15 & 325 & \multirow{2}{*}{3.68} \\
\hline & & 495 & 536 & 0 & 154 & 15 & 1199 & \\
\hline \multirow[t]{2}{*}{2} & \multirow{2}{*}{$\begin{array}{l}\text { A thorough review of source documents is one } \\
\text { core attribute of preventing payroll fraud. }\end{array}$} & 103 & 134 & 0 & 70 & 18 & 325 & \multirow{2}{*}{3.72} \\
\hline & & 515 & 536 & 0 & 140 & 18 & 1209 & \\
\hline \multirow[t]{2}{*}{3} & \multirow{2}{*}{$\begin{array}{l}\text { The arithmetical accuracy of payrolls can be } \\
\text { checked properly before recommending for } \\
\text { further necessary actions through the use of } \\
\text { forensic auditors. }\end{array}$} & 97 & 128 & 0 & 70 & 30 & 325 & \multirow[b]{2}{*}{3.59} \\
\hline & & 485 & 512 & 0 & 140 & 30 & 1167 & \\
\hline \multirow[t]{2}{*}{4} & \multirow{2}{*}{$\begin{array}{l}\text { Payroll fraud prevention ensures that no one } \\
\text { employee performs various aspects of salaries } \\
\text { and wages in the Bayelsa public sector. }\end{array}$} & 99 & 136 & 0 & 75 & 15 & 325 & \multirow[b]{2}{*}{3.70} \\
\hline & & 495 & 544 & 0 & 150 & 15 & 1204 & \\
\hline \multirow[t]{4}{*}{5} & \multirow{2}{*}{$\begin{array}{l}\text { Proper checking of clock cards, attendance } \\
\text { register and time recording by employees to } \\
\text { avoid earning manipulation. }\end{array}$} & 101 & 137 & 0 & 69 & 18 & 325 & \multirow[b]{2}{*}{3.72} \\
\hline & & 505 & 548 & 0 & 138 & 18 & 1209 & \\
\hline & TOTAL & 499 & 669 & 0 & 361 & 96 & 1625 & \multirow{2}{*}{3.68} \\
\hline & WEIGHTED MEAN & 100 & 134 & 0 & 72 & 19 & 325 & \\
\hline
\end{tabular}

Source: Field Survey 2020

Appendix: 2 Analysis and Classification responses of Evaluation of Biometric identification number on Payroll fraud prevention

Table 4. Evaluation of Biometric identification number on Payroll fraud prevention

\begin{tabular}{|c|c|c|c|c|c|c|c|c|}
\hline$S / N$ & ITEMS & $\begin{array}{l}\text { SA } \\
(5)\end{array}$ & $\begin{array}{c}A \\
(4)\end{array}$ & $\underset{(3)}{U}$ & $\begin{array}{c}D \\
(2)\end{array}$ & $\begin{array}{l}\text { SD } \\
(1)\end{array}$ & TOTAL & MEAN \\
\hline \multirow[t]{2}{*}{1} & \multirow{2}{*}{$\begin{array}{l}\text { Can biometrics identification reduce ghost } \\
\text { employees, false employee's claims and time } \\
\text { theft }\end{array}$} & 102 & 134 & 0 & 71 & 18 & 325 & \multirow[b]{2}{*}{3.71} \\
\hline & & 510 & 536 & 0 & 142 & 18 & 1206 & \\
\hline \multirow[t]{2}{*}{2} & \multirow{2}{*}{$\begin{array}{l}\text { Payroll fraud can be handled if the government } \\
\text { Payroll system is computerized. }\end{array}$} & 96 & 131 & 0 & 79 & 19 & 325 & \multirow{2}{*}{3.63} \\
\hline & & 480 & 524 & 0 & 158 & 19 & 1181 & \\
\hline \multirow[t]{2}{*}{3} & \multirow{2}{*}{$\begin{array}{l}\text { Payroll fraud can be reduced by the use of } \\
\text { Biometrics identification. }\end{array}$} & 99 & 134 & 0 & 77 & 15 & 325 & \multirow{2}{*}{3.69} \\
\hline & & 495 & 536 & 0 & 154 & 15 & 1200 & \\
\hline \multirow[t]{2}{*}{4} & \multirow{2}{*}{$\begin{array}{l}\text { Payroll fraud can be eliminated through the use } \\
\text { biometrics identification }\end{array}$} & 116 & 134 & 0 & 68 & 7 & 325 & \multirow{2}{*}{3.87} \\
\hline & & 580 & 536 & 0 & 136 & 7 & 1259 & \\
\hline \multirow[t]{4}{*}{5} & \multirow[t]{2}{*}{ Biometrics identification can stop Payroll fraud } & 99 & 136 & 0 & 75 & 15 & 325 & \multirow{2}{*}{3.70} \\
\hline & & 495 & 544 & 0 & 150 & 15 & 1204 & \\
\hline & TOTAL & 512 & 669 & 0 & 370 & 74 & 1625 & 3.72 \\
\hline & WEIGHTED MEAN & 102 & 134 & & 74 & 15 & 325 & \\
\hline
\end{tabular}

Source: Field Survey 2020 
Appendix: 3 Analysis and Classification responses of Evaluation of Bank verification number on Payroll fraud prevention

Table 5. Evaluation of Bank verification number on Payroll fraud prevention

\begin{tabular}{|c|c|c|c|c|c|c|c|c|}
\hline$S / N$ & ITEMS & $\begin{array}{l}\text { SA } \\
(5)\end{array}$ & $\begin{array}{c}A \\
(4)\end{array}$ & $\begin{array}{l}U \\
(3)\end{array}$ & $\begin{array}{c}D \\
(2)\end{array}$ & $\begin{array}{l}\text { SD } \\
(1)\end{array}$ & TOTAL & MEAN \\
\hline \multirow[t]{2}{*}{1} & \multirow{2}{*}{$\begin{array}{l}\text { Payroll fraud can be reduced by the use of bank } \\
\text { verification number (BVN). }\end{array}$} & 98 & 126 & 0 & 69 & 32 & 325 & \multirow{2}{*}{3.58} \\
\hline & & 490 & 504 & 0 & 138 & 32 & 1164 & \\
\hline \multirow[t]{2}{*}{2} & \multirow{2}{*}{$\begin{array}{l}\text { Payroll fraud can be eliminated through the use } \\
\text { of bank verification number (BVN). }\end{array}$} & 80 & 149 & 0 & 92 & 4 & 325 & \multirow{2}{*}{3.64} \\
\hline & & 400 & 596 & 0 & 184 & 4 & 1184 & \\
\hline \multirow[t]{2}{*}{3} & \multirow{2}{*}{$\begin{array}{l}\text { Bank verification Number (BVN) has a Significant } \\
\text { impact on elimination of ghost workers }\end{array}$} & 97 & 128 & 0 & 70 & 30 & 325 & \multirow{2}{*}{3.59} \\
\hline & & 485 & 512 & 0 & 140 & 30 & 1167 & \\
\hline \multirow[t]{2}{*}{4} & \multirow{2}{*}{$\begin{array}{l}\text { bank verification number (BVN) can reduce } \\
\text { Payroll fraud }\end{array}$} & 112 & 133 & 0 & 67 & 13 & 325 & \multirow{2}{*}{3.81} \\
\hline & & 560 & 532 & 0 & 134 & 13 & 1239 & \\
\hline \multirow[t]{4}{*}{5} & \multirow{2}{*}{$\begin{array}{l}\text { Bank verification number (BVN) can eliminate } \\
\text { Payroll fraud }\end{array}$} & 100 & 138 & 0 & 75 & 12 & 325 & \multirow{2}{*}{3.74} \\
\hline & & 500 & 552 & 0 & 150 & 12 & 1214 & \\
\hline & TOTAL & 487 & 674 & 0 & 373 & 91 & 1625 & \multirow{2}{*}{3.67} \\
\hline & WEIGHTED MEAN & 97 & 135 & 0 & 75 & 18 & 325 & \\
\hline
\end{tabular}

Source: Field Survey 2020

Appendix: 4 Analysis and Classification responses of Evaluation of Electronic transfer system on Payroll fraud prevention

Table 6. Evaluation of Electronic transfer system on Payroll fraud prevention

\begin{tabular}{|c|c|c|c|c|c|c|c|c|}
\hline$S / N$ & ITEMS & $\begin{array}{l}\text { SA } \\
(5)\end{array}$ & $\begin{array}{c}\text { A } \\
(4)\end{array}$ & $\begin{array}{c}\text { U } \\
(3)\end{array}$ & $\begin{array}{c}D \\
(2)\end{array}$ & $\begin{array}{l}\text { SD } \\
\text { (1) }\end{array}$ & TOTAL & MEAN \\
\hline \multirow[t]{2}{*}{1} & \multirow{2}{*}{ 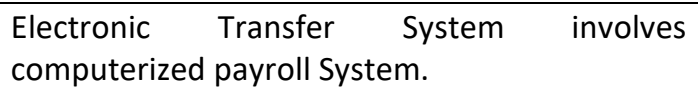 } & 103 & 134 & 0 & 70 & 18 & 325 & \multirow{2}{*}{3.72} \\
\hline & & 515 & 536 & 0 & 140 & 18 & 1209 & \\
\hline \multirow[t]{2}{*}{2} & \multirow{2}{*}{$\begin{array}{l}\text { Electronic Transfer System involves Biometrics } \\
\text { identification and bank Verification number } \\
\text { (BVN). }\end{array}$} & 101 & 137 & 0 & 69 & 18 & 325 & \multirow{2}{*}{3.72} \\
\hline & & 505 & 548 & 0 & 138 & 18 & 1209 & \\
\hline \multirow[t]{2}{*}{3} & \multirow{2}{*}{$\begin{array}{l}\text { Electronic Transfer system has a Significant } \\
\text { Impact in the elimination of Ghost workers }\end{array}$} & 95 & 132 & 0 & 78 & 20 & 325 & \multirow{2}{*}{3.63} \\
\hline & & 475 & 528 & 0 & 156 & 20 & 1179 & \\
\hline \multirow[t]{2}{*}{4} & \multirow{2}{*}{$\begin{array}{l}\text { Electronic Transfer system impacts Significantly } \\
\text { on the elimination of false Employee's claims. }\end{array}$} & 105 & 130 & 0 & 76 & 14 & 325 & \multirow{2}{*}{3.73} \\
\hline & & 525 & 520 & 0 & 152 & 14 & 1211 & \\
\hline \multirow[t]{4}{*}{5} & \multirow{2}{*}{$\begin{array}{l}\text { Electronic Transfer System impacts positively } \\
\text { on time theft }\end{array}$} & 108 & 130 & 0 & 74 & 13 & 325 & \multirow{2}{*}{3.76} \\
\hline & & 540 & 520 & 0 & 148 & 13 & 1221 & \\
\hline & TOTAL & 512 & 663 & 0 & 367 & 83 & 1625 & \multirow{2}{*}{3.71} \\
\hline & WEIGHTED MEAN & 102 & 133 & 0 & 73 & 17 & 325 & \\
\hline
\end{tabular}

Source: Field Survey 2020 